\title{
A46G and C79G polymorphisms in the $\beta 2$-adrenergic receptor gene (ADRB2) and essential hypertension risk: a meta-analysis
}

\author{
Yuqing Lou ${ }^{1,4}$, Jinghua Liu ${ }^{2,4}$, Yan Huang ${ }^{3}$, Jielin $\mathrm{Liu}^{1}$, Zuoguang Wang ${ }^{1}$, Ya Liu ${ }^{1}, \mathrm{Zhizhong} \mathrm{Li}^{2}, \mathrm{Yao} \mathrm{Li}^{3}$, \\ $\mathrm{Yi} \mathrm{Xie}^{3}$ and Shaojun Wen ${ }^{1,5}$
}

No consensus has been reached on the association between the $\beta 2$-adrenergic receptor polymorphisms $A 46 \mathrm{G}$ and $\mathrm{C79G}$ and essential hypertension risk. We performed a meta-analysis to confirm the possible association. After reviewing 303 reports in PubMed and 359 reports in Embase, we included in our meta-analysis 18 articles (20 studies) that met our inclusion criteria. The fixed-effects model and the random-effects model were applied for dichotomous outcomes to combine the results of the individual studies. There was no statistical association between A46G and hypertension risk in all subjects, Asians or Caucasians. However, an association was observed in the dominant genetic model ( $A A$ vs. ( $A G+G G))(P=0.04$, odds ratio $(\mathrm{OR})=1.38,95 \%$ confidence interval $(\mathrm{Cl}) 1.01-1.87, P_{\text {heterogeneity }}=0.98$, fixed-effects model) in the subgroup of mixed Africans. No overall statistical association could be found between $\mathrm{C79G}$ and hypertension risk or any ethnic subgroup. In the research conducted on severe hypertension (systolic blood pressure $\geqslant 160 \mathrm{~mm} \mathrm{Hg}$ and/or diastolic blood pressure $\geqslant 95 \mathrm{~mm} \mathrm{Hg}$ hypertensive population), significant association was found in the dominant genetic model (CC vs. (CG+GG)) $(P=0.04$, $\mathrm{OR}=1.38,95 \% \mathrm{Cl} 1.02-1.86, P_{\text {heterogeneity }}=0.03$, random-effects model), and there was also a borderline significance between the $\mathrm{C} 79$ allele and severe hypertension $\left(P=0.05, \mathrm{OR}=1.26,95 \% \mathrm{Cl} 1.00-1.57, P_{\text {heterogeneity }}=0.04\right.$, random-effects model $)$. No association could be found in this study between the two polymorphisms and stage 2 hypertension. More studies stratified for different ethnicities and different stages of hypertension should be performed in the future.

Hypertension Research (2010) 33, 1114-1123; doi:10.1038/hr.2010.151; published online 26 August 2010

Keywords: adrenergic receptor; meta-analysis; polymorphism

\section{INTRODUCTION}

Essential hypertension is an escalating problem in modern society. It is widely considered a complex genetic trait caused by multiple susceptibility genes, the effects of which are modulated by gene-environment and gene-gene interactions. ${ }^{1}$ As a consequence, many gene polymorphisms have been assessed as candidate determinants of the risk of hypertension.

At the molecular level, the role of the $\beta 2$-adrenergic receptor, $A D R B 2$, in hypertension has been extensively evaluated, paying particular attention to the rs1042713 (Arg16Gly, A46G) and rs1042714 (Gln27Glu, C79G) single-nucleotide polymorphisms on chromosome $5 \mathrm{q} 31$ to $32 .{ }^{2}$ In vitro, compared with wild-type A46, the G46 allele displayed normal agonist binding and functional coupling to Gs, resulting in the stimulation of adenylyl cyclase activity. Similar results were found in the comparison between the C79 and G79 alleles. ${ }^{3}$ In clinical and epidemiologic populations, some studies have indicated that the A46G polymorphism ${ }^{4-10}$ as well as the C79G polymorphism $^{5,6,8,10,11}$ in the $A D R B 2$ gene is associated with essential hypertension (or BP level). Other studies have been unable to replicate these findings. ${ }^{12-20}$ Therefore, in spite of the large number of previous reports about the association between these two polymorphisms and hypertension, the conclusion remains unclear. To clarify the effect of A46G and C79G polymorphisms on the risk of hypertension, we conducted a meta-analysis from all eligible case-control studies published to date.

\footnotetext{
${ }^{1}$ Department of Hypertension Research, Beijing Anzhen Hospital, Capital Medical University and Beijing Institute of Heart Lung and Blood Vessel Diseases, Beijing, PR China; ${ }^{2}$ Department of Cardiology, Beijing Anzhen Hospital, Capital Medical University, Beijing, PR China and ${ }^{3}$ State Key Laboratory of Genetic Engineering, Institute of Genetics, School of Life Sciences, Fudan University, Shanghai, PR China

${ }^{4}$ These authors contributed equally to this work.

${ }^{5}$ Member of International Society of Hypertension.

Correspondence: Dr S Wen, Department of Hypertension Research, Beijing Anzhen Hospital, Capital Medical University and Beijing Institute of Heart Lung and Blood Vessel Diseases, 2 Anzhen Road, Beijing 100029, PR China.

E-mail: wenshaojun@yahoo.com.cn

or Dr Y Xie, School of Life Sciences, Institute of Genetics, Fudan University, Room 605 Science Building, 220 Handan Road, Shanghai 200433 , PR China.

E-mail: yxie@fudan.edu.cn
}

Received 9 February 2010; revised 12 May 2010; accepted 1 June 2010; published online 26 August 2010 


\section{MATERIALS AND METHODS}

\section{Identification and eligibility of relevant studies}

To identify all the studies that examined the association of A46G and C79G polymorphisms with hypertension, we conducted a computerized literature search of PubMed and Embase databases (before January 2010) using the following keywords and subject terms: 'adrenergic' or 'adrenoceptor', 'polymorphism' and 'hypertension'. References of retrieved articles were also screened. If an article reported results on different ethnic sub-populations, each sub-population was treated as a separate study in our meta-analysis. Studies included in the meta-analysis had to meet all the following criteria: (i) use of an unrelated case-control design, (ii) available genotype frequency, (iii) the genotype distribution of the control population must be in HardyWeinberg equilibrium (HWE) and (iv) hypertension defined as systolic blood pressure $(\mathrm{SBP}) \geqslant 140 \mathrm{~mm} \mathrm{Hg}$ and/or diastolic blood pressure $(\mathrm{DBP}) \geqslant$ $90 \mathrm{~mm} \mathrm{Hg}$ and/or treatment with antihypertensive medication; stage 2 hypertension was defined as $\mathrm{SBP} \geqslant 160 \mathrm{~mm} \mathrm{Hg}$ and/or $\mathrm{DBP} \geqslant 100 \mathrm{~mm} \mathrm{Hg} .{ }^{21-22}$ To minimize bias in the selection of studies, two observers independently extracted the information from each study. Disagreements were resolved in consensus by discussion between the authors. If a paper did not provide relevant data, or if the data provided were not sufficient, we contacted corresponding or original authors by e-mail in order to obtain the raw data.

\section{Data extraction}

Data were collected on the genotype of A46G and C79G according to ethnicity. First author, year of publication, diagnostic standards of each study, number of cases and controls, number and frequency of genotypes, and allele frequency of both polymorphisms in cases and controls are described in Tables $1,2 \mathrm{a}$ and $\mathrm{b}$.

\section{Statistical analysis}

The strength of the association of A46G and C79G with hypertension was measured by an odds ratio (OR) corresponding to a $95 \%$ confidence interval (CI), which was calculated according to the method used by Woolf. ${ }^{23}$ We examined the association between allele A of A46G and hypertension, as well as the dominant genetic model (AA vs. GG + AG), the recessive genetic model (AA + AG vs. GG) and homozygote comparison (AA vs. GG). The same method was applied to analysis of the C79G polymorphism. In our study, two models of meta-analysis were applied for dichotomous outcomes in ReviewManager 4.2 software (The Cochrane Collaboration, Oxford, UK): the fixedeffects model and the random-effects model. The fixed-effects model, using the Mantel-Haenszel method, assumed that studies were sampled from populations with the same effect size, making an adjustment to the study weights according to the in-study variance. The random-effects model, using the DerSimonian and Laird method, assumed that studies were taken from populations with varying effect sizes and calculated study weights both from in-study and between-study variances, with consideration of the extent of variation or heterogeneity. We performed a $X^{2}$-based $Q$ statistic test to assess the between-study heterogeneity. ${ }^{24}$ Heterogeneity was considered significant for $P<0.10$ because of the low power of the statistic. The random-effects model (if $P<0.10$ ) or the fixed-effects model (if $P>0.10$ ) was used to pool the results. ${ }^{25}$ The significance of the pooled OR was determined by the $Z$ test and a $P$-value of $<0.05$ was considered significant. For each genetic comparison, subgroup analysis according to ethnicity was considered for Asian, Caucasian and mixed African populations to estimate ethnic-specific OR. The subgroup 'mixed African' included the African-American population and the Black South African population. Subgroup analysis according to different stages of hypertension was considered for stage 2 hypertension and severe hypertension. We defined the criterion of SBP $\geqslant 160 \mathrm{~mm} \mathrm{Hg}$ and/or DBP $\geqslant 95 \mathrm{~mm} \mathrm{Hg}$ as 'severe hypertension' based on stage 2 hypertension, in order to expand the sample size by including the research of Kato et al. ${ }^{16}$

When unexpected heterogeneity was detected, sensitivity analysis was performed to examine specific sensitivity of the findings. This was done by examining and recalculating the pooled association sizes and joint values of $P$ in homogeneous subgroups, as well as after excluding studies one by one.

Publication bias was investigated by funnel plot, in which the standard error of the $\log (\mathrm{OR})$ of each study was plotted against its OR. Funnel plot suggested possible publication bias, which was also assessed by Egger's linear regression test. ${ }^{26}$ In addition, we performed a $t$-test to determine the significance of the intercept, and a $P$-value of $<0.05$ was considered significant.

HWE was tested by the $X^{2}$-test for goodness of fit based on a web program (http://ihg.gsf.de/cgi-bin/hw/hwal.pl). Analyses were performed using the software Stata version 7 (Stata, College Station, TX, USA) and ReviewManager 4.2. All $P$-values were two-sided.

Table 1 Characteristics of eligible studies considered in the meta-analysis

\begin{tabular}{|c|c|c|c|c|c|}
\hline Ethnicity & First author (year) & $\begin{array}{l}\text { Single-nucleotide } \\
\text { polymorphism }\end{array}$ & Case no. & Control no. & Diagnostic standard \\
\hline Asian & Misonoa $(2009)^{7}$ & A46G & 194 & 208 & $S B P \geqslant 140, D B P \geqslant 90$ \\
\hline Asian & Yu $(2008)^{9}$ & A46G, C79G & 58 & 58 & $S B P \geqslant 140, D B P \geqslant 90$ \\
\hline Asian & Mo $(2007)^{11}$ & C79G & 288 & 149 & $S B P \geqslant 140, D B P \geqslant 90$ \\
\hline Asian & Wu CHN-Hani $(2006)^{5}$ & A46G, C79G & 172 & 133 & $\mathrm{SBP} \geqslant 140, \mathrm{DBP} \geqslant 90$ \\
\hline Asian & Wu CHN-Yi $(2006)^{5}$ & A46G, C79G & 99 & 134 & $\mathrm{SBP} \geqslant 140, \mathrm{DBP} \geqslant 90$ \\
\hline Asian & $\mathrm{Ge}(2005)^{10}$ & C79G & 503 & 504 & $\mathrm{SBP} \geqslant 160, \mathrm{DBP} \geqslant 100$ \\
\hline Asian & Kato $(2001)^{16}$ & A46G, C79G & 1141 & 852 & $\mathrm{SBP} \geqslant 160, \mathrm{DBP} \geqslant 95$ \\
\hline Caucasian & Gjesing $(2007)^{20}$ & A46G, C79G & 2511 & 3984 & $\mathrm{SBP} \geqslant 140, \mathrm{DBP} \geqslant 90$ \\
\hline Caucasian & Bartels $(2007)^{15}$ & A46G, C79G & 258 & 171 & $\mathrm{SBP} \geqslant 140, \mathrm{DBP} \geqslant 90$ \\
\hline Caucasian & Pojoga $(2006)^{6}$ & A46G, C79G & 280 & 65 & $\mathrm{DBP} \geqslant 90$ (with treatment) or $\mathrm{DBP} \geqslant 100$ \\
\hline Caucasian & Filigheddu $(2004)^{4}$ & A46G & 517 & 184 & $\mathrm{SBP} \geqslant 140, \mathrm{DBP} \geqslant 90$ \\
\hline Caucasian & Castellano $(2003)^{8}$ & A46G, C79G & 324 & 247 & $S B P \geqslant 140, D B P \geqslant 90$ \\
\hline Caucasian & Sunder-Plassmann (2002) ${ }^{13}$ & A46G, C79G & 182 & 182 & $\mathrm{DBP} \geqslant 120$ \\
\hline Caucasian & Herrmann SM (2002) $)^{17}$ & A46G, C79G & 707 & 290 & $\mathrm{DBP} \geqslant 100$ \\
\hline Caucasian & Herrmann V (2000) $)^{18}$ & A46G & 36 & 101 & $S B P \geqslant 140, D B P \geqslant 95$ \\
\hline Caucasian & Xie $(2000)^{14}$ & A46G, C79G & 201 & 179 & $S B P \geqslant 140, D B P \geqslant 90$ \\
\hline Caucasian & Jia $(2000)^{19}$ & C79G & 298 & 298 & $\mathrm{SBP} \geqslant 160, \mathrm{DBP} \geqslant 90$ \\
\hline Mixed African & Tang $(2003)^{27}$ & A46G & 134 & 143 & $\mathrm{SBP} \geqslant 160, \mathrm{DBP} \geqslant 100$ \\
\hline Mixed African & Xie $(2000)^{14}$ & A46G, C79G & 155 & 128 & $\mathrm{SBP} \geqslant 140, \mathrm{DBP} \geqslant 90$ \\
\hline Mixed African & Candy $(2000)^{12}$ & A46G, C79G & 192 & 123 & $\mathrm{DBP} \geqslant 90$ \\
\hline
\end{tabular}

Abbreviations: DBP, diastolic blood pressure; SBP, systolic blood pressure. 
Table 2a Characteristics of studies and the distribution of ADRB2 A46G genotypes and alleles among hypertension of cases and controls in the meta-analysis

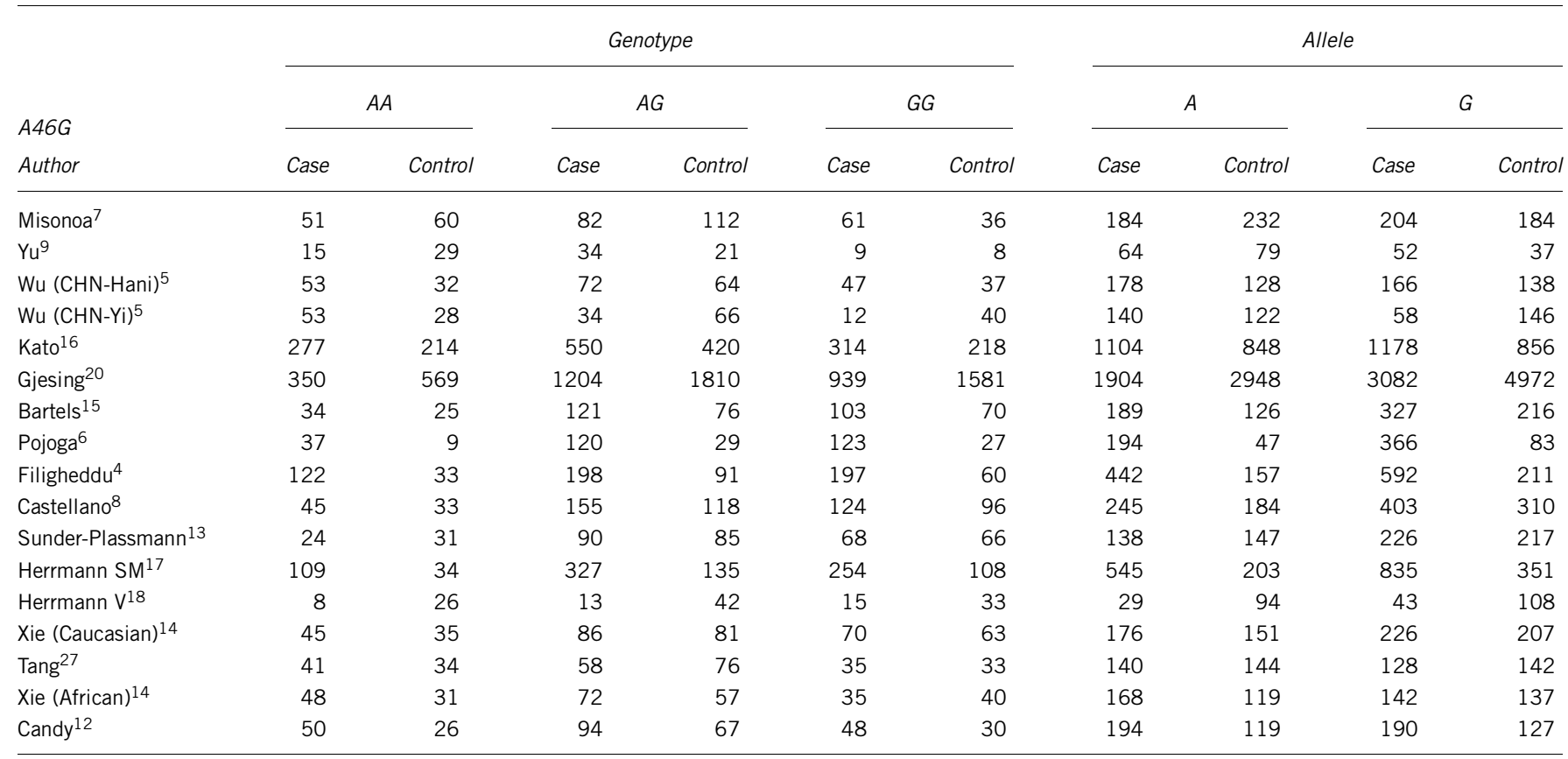

Table $2 \mathrm{~b}$ Characteristics of studies and the distribution of ADRB2 C79G genotypes and alleles among hypertension of cases and controls in the meta-analysis

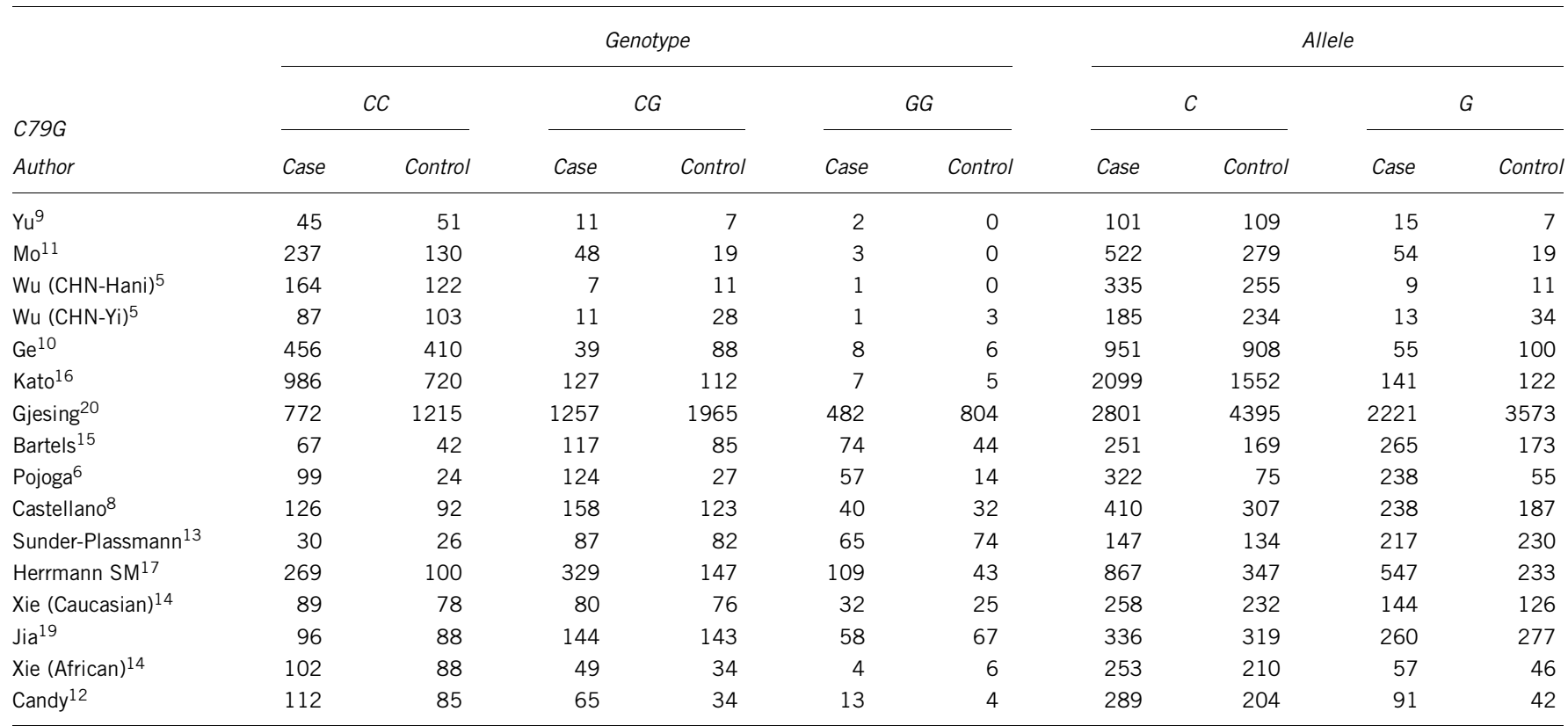

\section{RESULTS}

\section{Selection of studies}

Through literature search and selection based on the inclusion criteria, 19 articles (23 studies) were identified by reviewing 303 articles in PubMed and 359 articles in Embase. ${ }^{4-20,27,28}$ Of the 19 eligible articles, the study of Gu et al. ${ }^{28}$ was replaced by their earlier report, ${ }^{10}$ as these two articles reported the same data. Wu et al. ${ }^{5}$ provided data on two Chinese minorities, the Hani and $\mathrm{Yi}$, residents of the remote rural area of Yunnan, China. ${ }^{29}$ The population of the two minorities was also grouped in to Asian. ${ }^{30}$ Tang et al., ${ }^{27}$ Herrmann et al. ${ }^{18}$ and Xie et al. ${ }^{14}$ provided data on two ethnicities: Caucasian American and AfricanAmerican. The genotyping data of the normotensive controls in the population Caucasian-American in Tang et al. ${ }^{27}\left(P_{\mathrm{HWE}}=0.048\right)$, and the African-American control subjects studied in Herrmann et al. ${ }^{18}$ $\left(P_{\mathrm{HWE}}=0.027\right)$ deviated from HWE. The same occurred with the data provided in Mo et al. ${ }^{11}\left(P_{\mathrm{HWE}}<0.001\right)$, Ge et al. ${ }^{10}\left(P_{\mathrm{HWE}}=0.040\right)$ and 


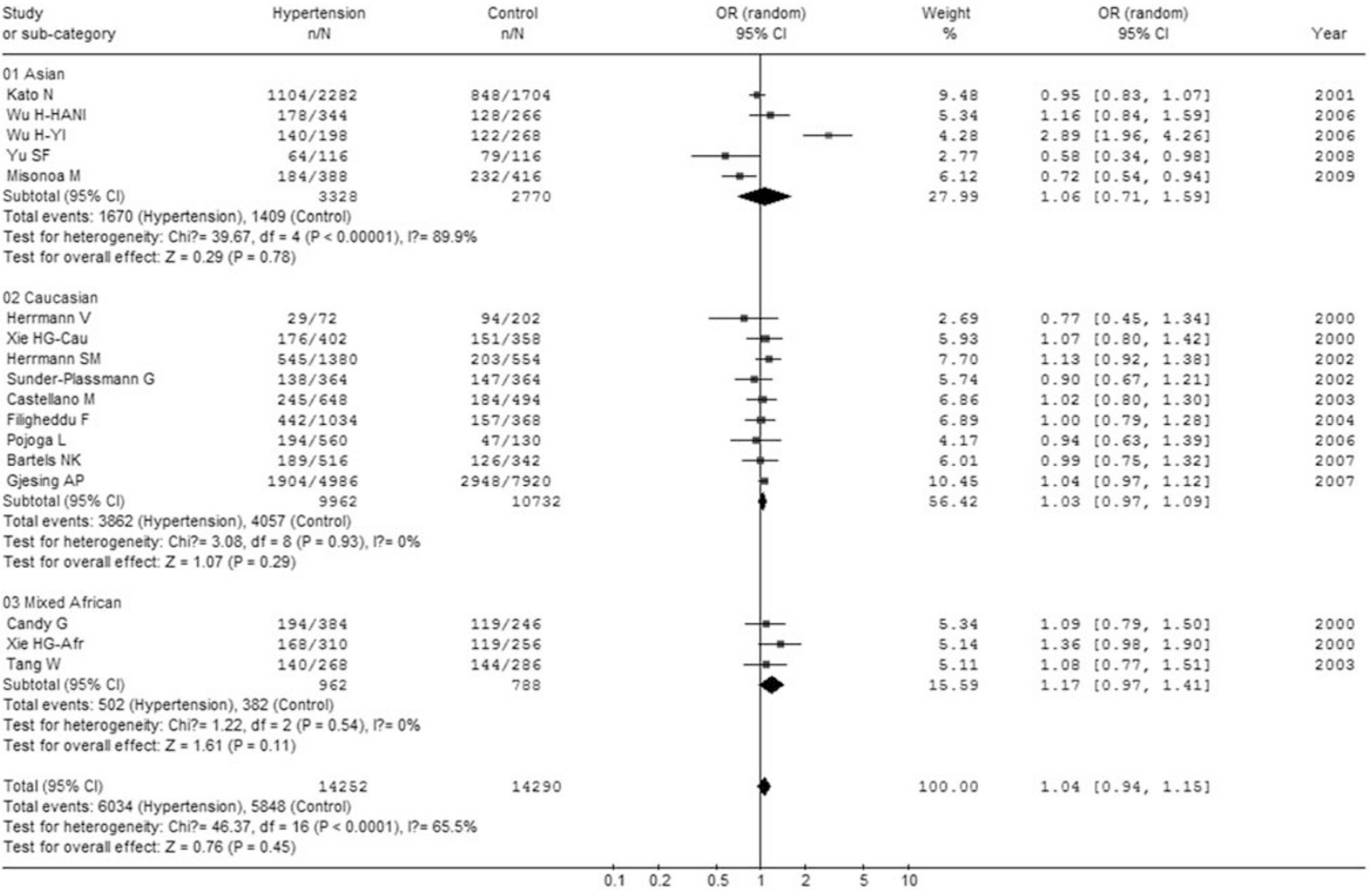

b Review:

Comparison: $\quad A A$ vs. $(A G+G G)$

Outcome: Miced African

\begin{tabular}{|c|c|c|c|c|c|c|c|}
\hline $\begin{array}{l}\text { Study } \\
\text { or sub-category }\end{array}$ & $\begin{array}{l}\text { Hypertension } \\
n / N\end{array}$ & $\begin{array}{c}\text { Control } \\
n / N\end{array}$ & $\begin{array}{l}\text { OR (foxed) } \\
95 \% \mathrm{Cl}\end{array}$ & $\begin{array}{c}\text { Weight } \\
\%\end{array}$ & & $\begin{array}{l}\text { OR (foxed) } \\
95 \% \mathrm{Cl}\end{array}$ & Year \\
\hline Geoff Candy & $50 / 192$ & $26 / 123$ & $-1=$ & 33.63 & 1.31 & {$[0.77,2.25]$} & 2000 \\
\hline Hong-Guang Xie-Afr & $48 / 155$ & $31 / 128$ & $-1=-$ & 33.63 & 1.40 & {$[0.83,2.38]$} & 2000 \\
\hline Weihong Tang & $41 / 134$ & $34 / 143$ & $1=$ & 32.75 & 1.41 & {$[0.83,2.41]$} & 2003 \\
\hline $\begin{array}{l}\text { Total }(95 \% \mathrm{Cl}) \\
\text { Total events: } 139 \text { (Hyp } \\
\text { Test for heterogeneity } \\
\text { Test for overall effect. }\end{array}$ & $\begin{array}{l}\quad 481 \\
(\text { Control) } \\
f=2(P=0.98), \\
0.04)\end{array}$ & 394 & & 100.00 & 1.38 & {$[1.01,1.87\}$} & \\
\hline
\end{tabular}

Figure 1 (a) Meta-analysis of the overall association between the A46G polymorphism and hypertension comparing A vs. G. $n$ indicates the total number of $A$ alleles; $N$ indicates the total number of $A$ alleles plus $G$ alleles. (b) Meta-analysis for the association between the A46G polymorphism and hypertension comparing $A A$ vs. $A G+G G$ in the subgroup of mixed Africans. $n$ indicates the total number of the $A A$ genotype; $N$ indicates the total number of the AA genotype plus the $A G+G G$ genotype.

Jia et al. ${ }^{19}\left(P_{\mathrm{HWE}}=0.041\right)$ for the A46G polymorphism. Thus, those sub-population studies were excluded. No study of the C79G polymorphism was excluded because the data deviated from HWE. Finally, 18 articles (20 studies) were included in our analysis (Table 1). All studies used blood samples for genotyping.

\section{Summary statistics}

A total of 7126 hypertension patients and 7145 controls for A46G, as well as 7346 hypertension patients and 7482 controls for C79G, were investigated. The allele frequencies were calculated for controls from the corresponding genotype distributions (Tables 2a and b). A46G allele $\mathrm{G}$ had a higher representation in cases and controls of Caucasians (61.2 and 62.2\%, respectively) than of Asians (49.8 and $49.1 \%$, respectively) and of the mixed African population (47.8 and 51.5\%, respectively). The overall prevalence of G46 was $57.7 \%$ in cases and $59.1 \%$ in controls. C79G allele $\mathrm{G}$ had a much lower representation in cases and controls of Asians (6.4 and 8.1\%, respectively) than of Caucasians (43.4 and 44.8\%, respectively) and of the mixed African population (21.4 and $17.5 \%$, respectively). The overall prevalence of G79 was $31.1 \%$ in cases and $35.0 \%$ in controls. 
Table 3 OR $(95 \% \mathrm{Cl})$ of the association of the A46G and C79G polymorphisms and hypertension in different subgroups under various genetic contrasts

\begin{tabular}{|c|c|c|c|c|}
\hline Contrast & Comparisons (study numbers) & $\mathrm{P}_{\text {heterogeneity }}$ & $\mathrm{P}^{*}$ value & OR $(95 \% \mathrm{Cl})$ \\
\hline \multicolumn{5}{|c|}{ A46G in hypertension } \\
\hline \multirow[t]{5}{*}{ A vs. G } & Overall (17) & $<0.0001$ & $0.45^{a}$ & $1.04(0.94-1.15)$ \\
\hline & Asian (5) & $<0.00001$ & $0.78^{a}$ & $1.06(0.71-1.59)$ \\
\hline & Caucasian (9) & 0.93 & 0.28 & $1.03(0.97-1.09)$ \\
\hline & Mixed African (3) & 0.54 & 0.11 & $1.17(0.97-1.41)$ \\
\hline & Stage 2 hypertension (3) & 0.47 & 0.47 & $1.06(0.91-1.23)$ \\
\hline \multirow[t]{5}{*}{$A A$ vs. $(A G+G G)$} & Overall (17) & 0.0002 & $0.17^{a}$ & $1.13(0.95-1.35)$ \\
\hline & Asian (5) & $<0.00001$ & $0.64^{a}$ & $1.15(0.64-2.06)$ \\
\hline & Caucasian (9) & 0.61 & 0.70 & $1.02(0.91-1.15)$ \\
\hline & Mixed African (3) & 0.98 & 0.04 & $1.38(1.01-1.87)$ \\
\hline & Stage 2 hypertension (3) & 0.19 & 0.25 & $1.18(0.89-1.56)$ \\
\hline \multirow[t]{5}{*}{$(\mathrm{A} A+\mathrm{AG})$ vs. $\mathrm{GG}$} & Overall (17) & 0.01 & $0.81^{a}$ & $0.98(0.87-1.12)$ \\
\hline & Asian (5) & 0.0005 & $0.96^{a}$ & $0.99(0.60-1.62)$ \\
\hline & Caucasian (9) & 0.75 & 0.22 & $1.05(0.97-1.14)$ \\
\hline & Mixed African (3) & 0.25 & 0.58 & $1.09(0.80-1.48)$ \\
\hline & Stage 2 hypertension (3) & 0.68 & 0.89 & $1.02(0.82-1.26)$ \\
\hline \multirow[t]{5}{*}{ AA vs. GG } & Overall (17) & 0.002 & $0.43^{a}$ & $1.08(0.89-1.30)$ \\
\hline & Asian (5) & $<0.00001$ & $0.76^{a}$ & $1.12(0.55-2.26)$ \\
\hline & Caucasian (9) & 0.89 & 0.50 & $1.04(0.92-1.18)$ \\
\hline & Mixed African (3) & 0.59 & 0.12 & $1.35(0.93-1.96)$ \\
\hline & Stage 2 hypertension (3) & 0.32 & 0.46 & $1.13(0.82-1.54)$ \\
\hline \multicolumn{5}{|c|}{ C79G in hypertension } \\
\hline \multirow[t]{6}{*}{ C vs. G } & Overall (16) & 0.010 & $0.27^{a}$ & $1.06(0.96-1.18)$ \\
\hline & Asian (6) & 0.002 & $0.39^{a}$ & $1.19(0.80-1.79)$ \\
\hline & Caucasian (8) & 0.98 & 0.24 & $1.04(0.98-1.10)$ \\
\hline & Mixed African (2) & 0.19 & 0.11 & $0.79(0.59-1.06)$ \\
\hline & Stage 2 hypertension (3) & 0.01 & $0.11^{\mathrm{a}}$ & $1.30(0.94-1.81)$ \\
\hline & $\mathrm{SBP} \geqslant 160 \mathrm{~mm} \mathrm{Hg}, \mathrm{DBP} \geqslant 95 \mathrm{~mm} \mathrm{Hg}(4)^{\mathrm{b}}$ & 0.04 & $0.05^{a}$ & $1.26(1.00-1.57)$ \\
\hline \multirow[t]{6}{*}{ CC vs. $(C G+G G)$} & Overall (16) & 0.006 & $0.21^{\mathrm{a}}$ & $1.10(0.95-1.27)$ \\
\hline & Asian (6) & 0.002 & $0.26^{a}$ & $1.29(0.83-2.00)$ \\
\hline & Caucasian (8) & 0.98 & 0.36 & $1.04(0.95-1.14)$ \\
\hline & Mixed African (2) & 0.38 & 0.09 & $0.74(0.53-1.05)$ \\
\hline & Stage 2 hypertension (3) & 0.02 & $0.09^{a}$ & $1.47(0.94-2.30)$ \\
\hline & $\mathrm{SBP} \geqslant 160 \mathrm{~mm} \mathrm{Hg}, \mathrm{DBP} \geqslant 95 \mathrm{~mm} \mathrm{Hg}(4)^{\mathrm{b}}$ & 0.03 & $0.04^{a}$ & $1.38(1.02-1.86)$ \\
\hline \multirow[t]{6}{*}{$(\mathrm{CC}+\mathrm{CG})$ vs. $\mathrm{GG}$} & Overall (16) & 0.90 & 0.43 & $1.04(0.94-1.15)$ \\
\hline & Asian (6) & 0.79 & 0.38 & $0.75(0.39-1.44)$ \\
\hline & Caucasian (8) & 0.92 & 0.31 & $1.05(0.95-1.17)$ \\
\hline & Mixed African (2) & 0.11 & 0.63 & $0.82(0.37-1.83)$ \\
\hline & Stage 2 hypertension (3) & 0.55 & 0.75 & $1.05(0.80-1.37)$ \\
\hline & $\mathrm{SBP} \geqslant 160 \mathrm{~mm} \mathrm{Hg}, \mathrm{DBP} \geqslant 95 \mathrm{~mm} \mathrm{Hg}(4)^{\mathrm{b}}$ & 0.75 & 0.77 & $1.04(0.80-1.36)$ \\
\hline \multirow[t]{6}{*}{ CC vs. GG } & Overall (16) & 0.93 & 0.40 & $1.05(0.94-1.18)$ \\
\hline & Asian (6) & 0.74 & 0.48 & $0.79(0.41-1.51)$ \\
\hline & Caucasian (8) & 0.98 & 0.27 & $1.07(0.95-1.20)$ \\
\hline & Mixed African (2) & 0.10 & $0.78^{a}$ & $0.81(0.20-3.39)$ \\
\hline & Stage 2 hypertension (3) & 0.74 & 0.57 & $1.10(0.79-1.53)$ \\
\hline & $\mathrm{SBP} \geqslant 160 \mathrm{~mm} \mathrm{Hg}, \mathrm{DBP} \geqslant 95 \mathrm{~mm} \mathrm{Hg}(4)^{\mathrm{b}}$ & 0.89 & 0.59 & $1.09(0.79-1.50)$ \\
\hline
\end{tabular}

Abbreviations: $\mathrm{Cl}$, confidence interval; $\mathrm{DBP}$, diastolic blood pressure; $\mathrm{OR}$, odds ratio; $\mathrm{SBP}$, systolic blood pressure.

aRandom-effects estimate.

bSBP $\geqslant 160 \mathrm{~mm} \mathrm{Hg}$ and/or DBP $\geqslant 95 \mathrm{~mm} \mathrm{Hg}$ hypertension population.

*The $P$-value of $O R$ determined by the $Z$ test.

\section{Quantitative synthesis}

ADRB2 A46G. Global statistical results: The random-effects model was used to pool the results, as the between-study heterogeneity was significant. There was no significant association between the A46 allele and hypertension in all subjects $(P=0.45, \mathrm{OR}=1.04,95 \% \mathrm{CI} 0.94$ $1.15, P_{\text {heterogeneity }}<0.0001$ ) (Figure 1a). No evidence of association was found between $\mathrm{A} 46 \mathrm{G}$ and hypertension in the dominant genetic model (AA vs. (AG+GG) $(P=0.17, \mathrm{OR}=1.13,95 \%$ CI $0.95-1.35$, $\left.P_{\text {heterogeneity }}=0.0002\right)$ or in the recessive genetic model $((\mathrm{AA}+\mathrm{AG}) v s$. GG) $\left(P=0.81, \mathrm{OR}=0.98,95 \%\right.$ CI $\left.0.87-1.12, P_{\text {heterogeneity }}=0.01\right)$. With homozygote comparison (AA vs. GG), no association could be found $\left(P=0.43, \mathrm{OR}=1.08,95 \%\right.$ CI $\left.0.89-1.30, P_{\text {heterogeneity }}=0.002\right)$ (Table 3$)$. 


\section{Stratification analysis}

Significant heterogeneity existed in five studies of Asian populations. The random-effects model was used to pool the results. No significant association was found between ADRB2 A46G and hypertension in any statistical models (Table 3). The fixed-effects model was used to pool the results of the Caucasian and the mixed African populations, as the between-study heterogeneity was insignificant. In the Caucasian population, we found no significant association between ADRB2 A46G and hypertension (Table 3). In the mixed African population, a significant association was found between the dominant genetic model (AA vs. $(\mathrm{AG}+\mathrm{GG}))(P=0.04, \mathrm{OR}=1.38,95 \%$ CI 1.01-1.87, $\left.P_{\text {heterogeneity }}=0.98\right)$ (Figure $1 \mathrm{~b}$ ), while no significant association was found in other statistic models (Table 3 ).

No significant heterogeneity existed in three studies of stage 2 hypertension; ${ }^{13,17,27}$ the fixed-effects model was used to pool the results. There was no significant association between the A46 allele and stage 2 hypertension $(P=0.47, \mathrm{OR}=1.06,95 \%$ CI $0.91-1.23$, $\left.P_{\text {heterogeneity }}=0.47\right)$. No evidence of association between A46G and stage 2 hypertension in the dominant genetic model was found (AA $v$ s. $(\mathrm{AG}+\mathrm{GG}))\left(P=0.25, \mathrm{OR}=1.18,95 \%\right.$ CI $\left.0.89-1.56, P_{\text {heterogeneity }}=0.19\right)$. The same was true for the recessive genetic model ((AA+AG) vs. GG) $\left(P=0.89, \mathrm{OR}=1.02,95 \%\right.$ CI $\left.0.82-1.26, P_{\text {heterogeneity }}=0.68\right)$. In homozygote comparison (AA vs. GG), no association could be found $\left(P=0.46, \mathrm{OR}=1.13,95 \%\right.$ CI $\left.0.82-1.54, P_{\text {heterogeneity }}=0.32\right)$ (Table 3$)$.

ADRB2 C79G. Global statistical results: Significant between-study heterogeneity existed in 16 studies when we compared the $\mathrm{C}$ and $\mathrm{G}$ alleles of C79G in relation to hypertension. The random-effects model was used to pool the results. There was no significant association between the C79 allele and hypertension in all subjects $(P=0.27$, $\mathrm{OR}=1.06,95 \%$ CI $0.96-1.18, P_{\text {heterogeneity }}=0.01$ ) (Figure 2a). No evidence of association was seen between C79G and hypertension in the dominant genetic model (CC vs. (CG+GG)) $(P=0.21, \mathrm{OR}=1.10$, 95\% CI $\left.0.95-1.27, P_{\text {heterogeneity }}=0.006\right)$ or in the recessive genetic model $((\mathrm{CC}+\mathrm{CG})$ vs. $\mathrm{GG})(P=0.43, \mathrm{OR}=1.04,95 \% \mathrm{CI} 0.94-1.15$, $\left.P_{\text {heterogeneity }}=0.90\right)$. There was no significant association in homozygote comparison (CC vs. GG) $(P=0.40, \mathrm{OR}=1.05,95 \%$ CI 0.94 $1.18, P_{\text {heterogeneity }}=0.93$ ) (Table 3$)$.

\section{Stratification analysis}

Significant heterogeneity existed in six studies of Asians; the randomeffects model was used for allele comparison, and no significant association was found (Table 3). There was also no significant association found in other genetic models conducted using Asians (Table 3). The fixed-effects model was used to pool the results for the Caucasian and mixed African populations, as the between-study heterogeneity was insignificant. There was no significant association with hypertension found in either population (Table 3).

Meta-analysis in the subgroup of stage 2 hypertension could not find significant association with the $\mathrm{C} 79 \mathrm{G}$ polymorphism in the three studies included. ${ }^{10,13,17}$ No association was found between the C79 allele and stage 2 hypertension $(P=0.11, \mathrm{OR}=1.30,95 \%$ CI $0.94-1.81$, $P_{\text {heterogeneity }}=0.01$, random-effects model), in the dominant genetic model (CC vs. $(\mathrm{CG}+\mathrm{GG}))(P=0.09, \mathrm{OR}=1.47,95 \%$ CI $0.94-2.30$, $P_{\text {heterogeneity }}=0.02$, random-effects model $)$, in the recessive genetic model $((\mathrm{CC}+\mathrm{CG})$ vs. GG $)(P=0.75, \mathrm{OR}=1.05,95 \%$ CI $0.80-1.37$, $P_{\text {heterogeneity }}=0.55$, fixed-effects model $)$, or in the homozygote comparison (CC vs. GG) $(P=0.57, \mathrm{OR}=1.10,95 \%$ CI $0.79-1.53$, $P_{\text {heterogeneity }}=0.74$, fixed-effects model).

To uncover the potential association between C79G polymorphisms and hypertension, further research was conducted on severe hyperten- sion ( $\mathrm{SBP} \geqslant 160 \mathrm{~mm} \mathrm{Hg}$ and/or $\mathrm{DBP} \geqslant 95 \mathrm{~mm} \mathrm{Hg}$ hypertensive population); four studies were included ${ }^{10,13,16,17}$ (Table 4). Significant association was found in the dominant genetic model (CC vs. $(\mathrm{CG}+\mathrm{GG}))\left(P=0.04, \mathrm{OR}=1.38,95 \%\right.$ CI $1.02-1.86, P_{\text {heterogeneity }}=0.03$, random-effects model) (Figure $2 \mathrm{~b}$ ), and there was also a borderline significance between the C79 allele and hypertension $(P=0.05$, $\mathrm{OR}=1.26,95 \%$ CI $1.00-1.57, P_{\text {heterogeneity }}=0.04$, random-effects model) (Figure 2c), whereas no association was found in the recessive genetic model ( $(\mathrm{CC}+\mathrm{CG})$ vs. GG) $(P=0.77, \mathrm{OR}=1.04,95 \%$ CI 0.80 $1.36, P_{\text {heterogeneity }}=0.75$, fixed-effects model) or in homozygote comparison (CC vs. GG) $(P=0.59, \quad \mathrm{OR}=1.09, \quad 95 \%$ CI $0.79-1.50$, $P_{\text {heterogeneity }}=0.89$, fixed-effects model).

\section{Sensitivity analysis}

Between-study heterogeneity existed in all the studies using Asian subjects, but not in those using Caucasians and mixed African populations. Sensitivity analysis was conducted by sequential omission of individual studies overall and of Asians. As such, the Wu et al. ${ }^{5}$ article on the Yi Chinese minority was excluded; it appeared that the overall between-study heterogeneity no longer existed for the A46G polymorphism and no association could be found (A vs. G, $P=0.61$, $\mathrm{OR}=1.01,95 \%$ CI $0.96-1.06, P_{\text {heterogeneity }}=0.22$, fixed-effects model). A similar result was found in the study of Ge et al. ${ }^{10}$ on the Han Chinese and prevalence of the $\mathrm{C} 79 \mathrm{G}$, which was also excluded; it appeared there was no association found overall (C vs. G, $P=0.29$, $\mathrm{OR}=1.03,95 \%$ CI $0.98-1.09, P_{\text {heterogeneity }}=0.18$, fixed-effects model). However, in the Asian population, between-study heterogeneity still existed when any single study was excluded.

\section{Publication bias}

The funnel plot was applied for comparison of A46 vs. G46 in the OR analysis of ADRB2 A46G, and Egger's test provided no evidence for funnel-plot asymmetry ( $t=-0.17, P=0.868$; Figure $3 \mathrm{a})$. Similarly, no publication bias was detected for the C79G polymorphism $(t=-0.21$, $P=0.838$; Figure $3 \mathrm{~b}$ ).

\section{DISCUSSION}

We performed a systematic review of the literature by means of a meta-analysis on the association between the ADRB2 A46G and C79G polymorphisms and essential hypertension, without evidence of publication bias for the outcome. To avoid reporting bias, we contacted the authors for raw data. We acquired the data, including 6495 Caucasian subjects from Gjesing et al., ${ }^{20}$ but failed to gain information from two original studies ${ }^{31,32}$ of Asians, which included 1700 subjects altogether. These two papers both indicated 'negative' results of A46G and C79G polymorphisms, which were consistent with our results of meta-analysis in Asians and overall.

Sensitivity analysis revealed that when two studies on Chinese subjects $^{5,10}$ were excluded, significant overall heterogeneity did not exist. The source of heterogeneity might be attributed to two factors. The first is the genetic difference in the sub-ethnic groups of the Chinese population. In the $\mathrm{Wu}$ et al. study, ${ }^{5}$ the ethnic minorities Yi and Hani were recruited for the analysis but not the Han ethnic majority. The genetic differences between these populations should not be neglected. ${ }^{30}$ Even in Han Chinese, a recent genomewide association study suggested that certain genetic characteristics of the Han population correlated with geographical locations. ${ }^{33}$ The genetic difference made it such that heterogeneity in the metaanalysis was inevitable. Another source of heterogeneity might be related to the quality of the studies, such as small samples and different inclusion criteria. Multicenter genome-wide association 
a Review:

Review: ADRB2 C79G \& Hypertension

Comparison: C vs. G

Outcome: Overall

Study

or sub-category

Hypertension

$\mathrm{n} N \mathrm{~N}$

$\%$

$95 \% \mathrm{Cl}$

Year

01 Asian

Kato $N$

$\mathrm{Ge} D$

$2099 / 2240$

$951 / 1006$ $95 \% \mathrm{Cl}$

$1.17[0.91,1.50]$

8.31

$1.90[1.35,2.68]$

$1552 / 1674$

$335 / 344 \quad 255 / 266$

Wu H-YI

$185 / 198$

$255 / 266$
$234 / 268$

MoW

$522 / 576$

$279 / 298$

$109 / 116$

Subtotal $(95 \% \mathrm{Cl})$

$101 / 116$

3630

Total events: 4193 (Hypertension), 3337 (Control)

Test for heterogeneity: Chi? = 18.84, df $=5(P=0.002), 1 ?=73.5 \%$

Test for overall effect: $Z=0.86(P=0.39)$

02 Caucasian

Jia H

Xe HG-Cau

Sunder-Plassmann

Castellano $\mathrm{M}$

Pojoga L

Bartels NK

Gjesing AP

Subtotal ( $95 \% \mathrm{Cl})$

$336 / 596 \quad 319 / 596$

$258 / 402 \quad 232 / 358$

$867 / 1414 \quad 347 / 580$

$147 / 364 \quad 134 / 364$

$410 / 648 \quad 307 / 494$

$322 / 560$

$251 / 516$

9522

$169 / 342$
$4395 / 7968$

Total events: 5392 (Hypertension), 5978 (Control)

Test for heterogeneity: Chi? $=1.65, \mathrm{df}=7 \quad(P=0.98), 1 ?=0 \%$

Test for overall effect: $Z=1.18(P=0.24)$

03 Moxed African

Candy G

Xie HG-Afr

$289 / 380$
$253 / 310$

253/310

Subtotal ( $95 \% \mathrm{Cl}$ )

Test for heterogenety: Chi? $=1.73, \mathrm{df}=1(P=0.19), 1 \mathrm{P}=42.1 \%$

Test for overall effect: $Z=1.17(P=0.24)$

Total (95\% Cl)

14692

10832

Total events: 10127 (Hypertension), 9729 (Control)

Test for heterogenety: Chi? = 30.70, df $=15(P=0.010), 1 ?=51.1 \%$

Test for overall effect: $Z=1.11(P=0.27)$

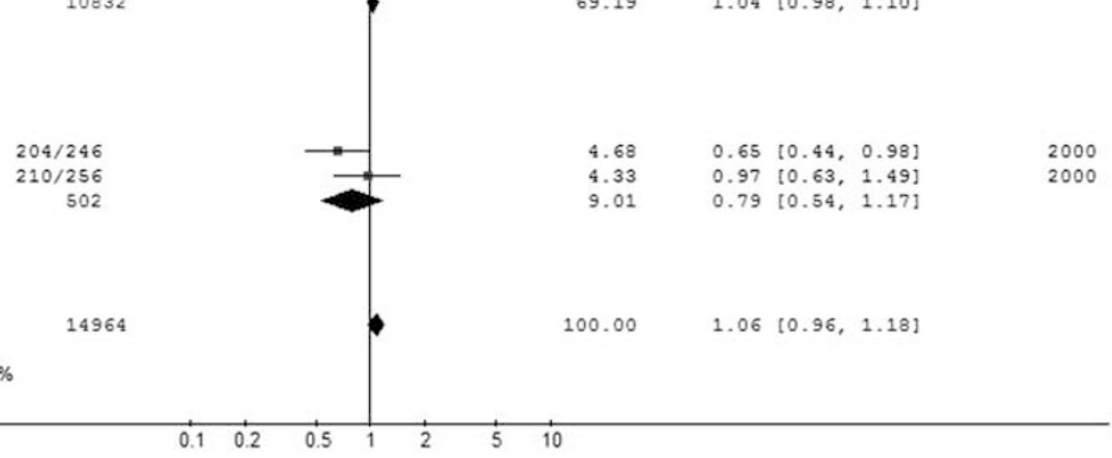

b Review:

ADRB2 C79G \& Hypertension

Comparison: CC vs. (CG+GG)

Outcome: Severe Hypertension (SBP>160 $\mathrm{mmH} g$ and/or $D B P>95 \mathrm{mmHg}$ )

\begin{tabular}{|c|c|c|c|c|c|c|c|}
\hline \multirow{2}{*}{$\begin{array}{l}\text { Study } \\
\text { or sub-category } \\
\text { Norihiro Kato }\end{array}$} & \multirow{2}{*}{$\begin{array}{c}\begin{array}{c}\text { Hypertension } \\
n / N\end{array} \\
986 / 1120\end{array}$} & \multirow{2}{*}{$\begin{array}{c}\begin{array}{c}\text { Control } \\
n / N\end{array} \\
720 / 837\end{array}$} & $\begin{array}{c}\text { OR (random) } \\
95 \% \mathrm{Cl}\end{array}$ & \multirow{2}{*}{$\begin{array}{c}\begin{array}{c}\text { Weight } \\
\%\end{array} \\
30.15\end{array}$} & \multicolumn{2}{|r|}{$\begin{array}{c}\text { OR (random) } \\
95 \% \mathrm{Cl}\end{array}$} & \multirow{2}{*}{$\begin{array}{l}\text { Year } \\
2001\end{array}$} \\
\hline & & & $=-$ & & 1.20 & {$[0.92,1.56]$} & \\
\hline Gere Sunder-Plassman & $30 / 182$ & $26 / 182$ & $\longrightarrow$ & 16.30 & 1.18 & {$[0.67,2.10]$} & 2002 \\
\hline D. Ge & $456 / 503$ & $410 / 504$ & $=-$ & 24.47 & 2.22 & {$[1.53,3.24]$} & 2005 \\
\hline $\begin{array}{l}\text { Total }(95 \% \mathrm{Cl}) \\
\text { Total events: } 1741 \text { (Hype } \\
\text { Test for heterogeneity: } \mathrm{C} \\
\text { Test for overall effect: } Z\end{array}$ & $\begin{array}{l}2512 \\
256 \text { (Control) } \\
f=3(P=0.03), \\
0.04)\end{array}$ & 1813 & & 100.00 & 1.38 & $(1.02,1.86]$ & \\
\hline
\end{tabular}

C Review

Review: ADRB2 C79G \& Hypertension

Comparison: Crs.G

Outcome: Severe Hypertension (SBP>160 $\mathrm{mmHg}$ and/or DBP>95mmHg)

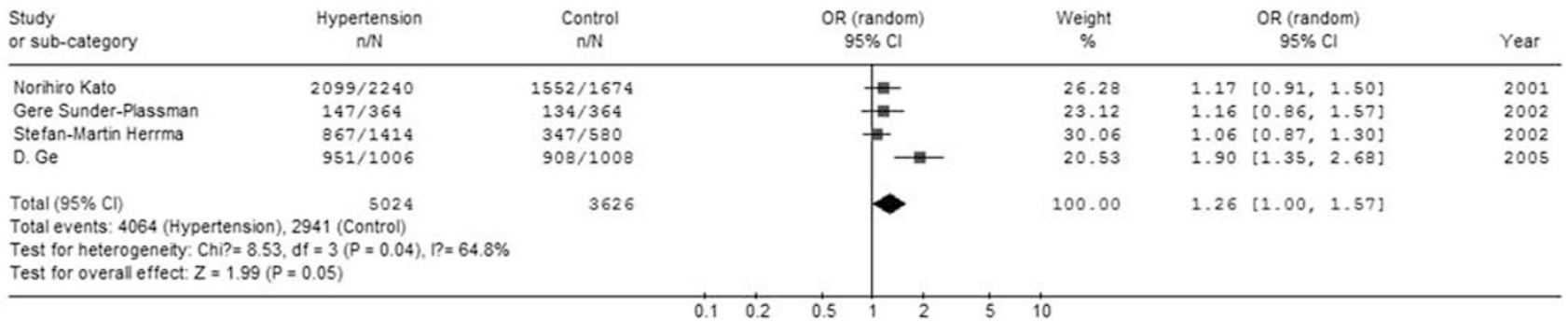


Table 4 Comparison of characteristics between cases and controls in the articles studied the association between 'severe hypertension' and ADRB2 C79G polymorphism

\begin{tabular}{|c|c|c|c|c|c|c|c|}
\hline First author & Country & Case/control & $\mathrm{n}, M / F$ & Age, year & $S B P, m m H g$ & $D B P, m m ~ H g$ & $B M I, \mathrm{kgm}^{-2}$ \\
\hline \multirow[t]{2}{*}{$\mathrm{Ge}^{10}$} & China & Case & $262 / 241$ & $53.57 \pm 9.34$ & $177.07 \pm 28.05$ & $104.34 \pm 12.28$ & $26.32 \pm 3.85$ \\
\hline & & Control & $263 / 241$ & $53.67 \pm 9.18$ & $117.58 \pm 11.65$ & $75.08 \pm 7.96$ & $24.34 \pm 3.57$ \\
\hline \multirow[t]{4}{*}{ Kato ${ }^{16}$} & Japan & Case (non-diabetic) & $440 / 402$ & $65.9 \pm 11.0$ & $160.3 \pm 19.3$ & $96.9 \pm 10.9$ & $23.5 \pm 3.0$ \\
\hline & & Control (non-diabetic) & $366 / 267$ & $58.9 \pm 13.2$ & $118.7 \pm 12.8$ & $75.3 \pm 9.0$ & $22.3 \pm 2.9$ \\
\hline & & Case (diabetic) & $192 / 113$ & $70.3 \pm 9.5$ & $156.3 \pm 19.5$ & $93.3 \pm 12.6$ & $24.5 \pm 3.6$ \\
\hline & & Control (diabetic) & $156 / 64$ & $71.6 \pm 10.0$ & $127.3 \pm 14.9$ & $79.0 \pm 8.9$ & $23.1 \pm 3.1$ \\
\hline \multirow[t]{2}{*}{ Sunder-Plassmann ${ }^{13}$} & Austria & Case & $91 / 91$ & $55.8 \pm 12.8$ & - & - & - \\
\hline & & Control & $91 / 91$ & $55.9 \pm 12.9$ & - & - & - \\
\hline \multirow[t]{2}{*}{ Herrmann ${ }^{17}$} & France, UK & Case (PEGASE study) & $403 / 304$ & $43.7 \pm 9.8$ & - & - & - \\
\hline & France & Control (ECTIM study) & $290 / 0$ & $51.1 \pm 8.8$ & - & - & - \\
\hline
\end{tabular}

Abbreviations: BMI, body mass index; DBP, diastolic blood pressure; SBP, systolic blood pressure; —, data not available. Values are mean \pm s.d.

a

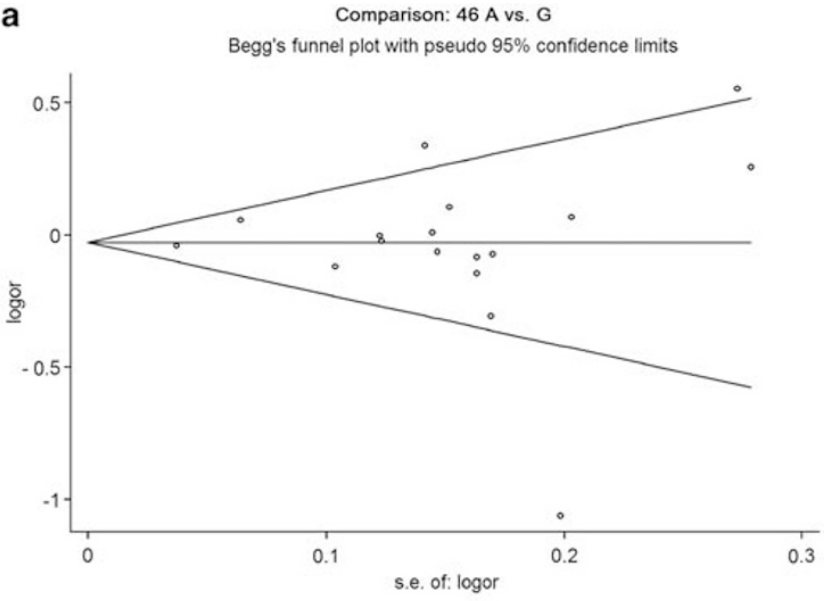

b

Begg's funnel plot with pseudo $95 \%$ confidence limits

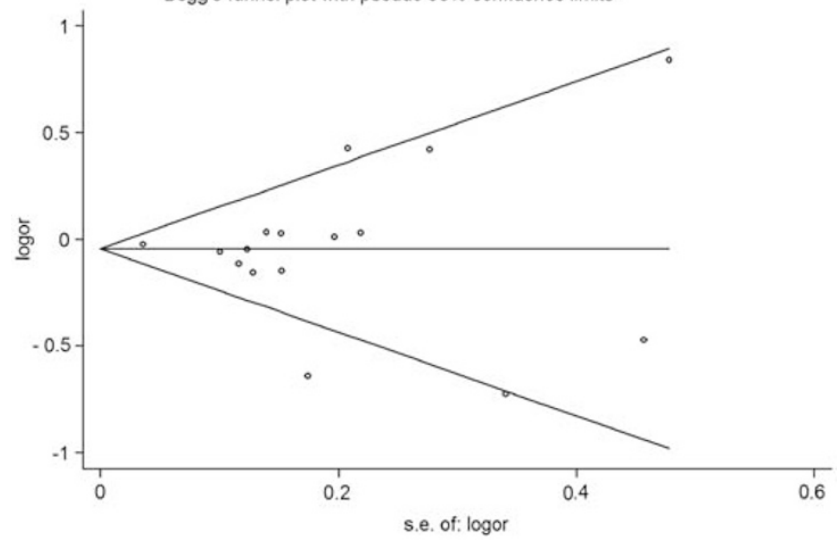

Figure 3 (a) Funnel plot for A vs. G allele comparison of the A46G polymorphism. (b) Funnel plot for C vs. G allele comparison of the C79G polymorphism. study with larger samples might help to elucidate the association between hundreds of thousands of locus variants and hypertension, which would minimize the heterogeneity of samples and would also examine the loci rarely studied by traditional single-nucleotide polymorphism genotyping technology. However, despite our best efforts, we have not found any genome-wide association study of this locus published.

In the meta-analysis of the association between the ADRB2 C79G polymorphism and hypertension, our results showed no overall association or an ethnicity-specific association. Similar results were found for the stage 2 hypertension population. Interestingly, the metaanalysis on 'severe hypertension' showed significant association between $\mathrm{C} 79 \mathrm{G}$ and hypertension in the dominant genetic model (CC vs. (CG+GG)), as well as in the comparison of the $\mathrm{C}$ and $\mathrm{G}$ alleles. We were curious to understand why an association occurred for particular criterion in the hypertensive population, but not in the population as a whole or in the subgroups of stage 2 hypertensives. Few studies (only three articles ${ }^{10,13,17}$ ) investigated the correlation between this polymorphism and stage 2 hypertension. When we defined 'severe hypertension', the sample size expanded by more than $80 \%$; by including the research of Kato et al., ${ }^{16}$ significant association could be found. To avoid overestimation by possible bias of other factors, we analyzed the detailed information of these four studies. Kato et al's study, involving both non-diabetic and diabetic patients (Table 4), deviated from the other three studies. To avoid potential bias because of diabetes, we excluded the diabetic subjects (294 hypertensive patients and 213 normotensive controls) and recalculated the pooled results. Significant association was stable in both models (CC vs. (CG+GG), $P=0.01, \mathrm{OR}=1.44,95 \% \mathrm{CI} 1.07-1.93$, $P_{\text {heterogeneity }}=0.05$, random-effects model; C vs. G, $P=0.03, \mathrm{OR}=1.30$, 95\% CI 1.03-1.66, $P_{\text {heterogeneity }}=0.03$, random-effects model).

Cockcroft et al. ${ }^{34}$ studied the regulation of the $\beta_{2}$-adrenoceptor on vessel resistance. The results indicate that homozygotes for A46 had significantly lower basal blood flow and attenuated increases in forearm blood flow compared with the G46 homozygotes, which

Figure 2 (a) Meta-analysis of the overall association between the C79G polymorphism and hypertension comparing C vs. G. $n$ indicates the total number of C alleles; $N$ indicates the total number of $C$ alleles plus $G$ alleles. (b) Meta-analysis for the association between the $C 79 \mathrm{G}$ polymorphism and systolic blood pressure $(\mathrm{SBP}) \geqslant 160 \mathrm{~mm} \mathrm{Hg}$ and/or diastolic blood pressure (DBP) $\geqslant 95 \mathrm{~mm} \mathrm{Hg}$ hypertension comparing CC vs. CG+GG. $n$ indicates the total number of the CC genotype; $N$ indicates the total number of the CC genotype plus the CG+GG genotype. (c) Meta-analysis for the association between the C79G polymorphism and $\mathrm{SBP} \geqslant 160 \mathrm{~mm} \mathrm{Hg}$ and/or $\mathrm{DBP} \geqslant 95 \mathrm{~mm} \mathrm{Hg}$ hypertension comparing $\mathrm{C}$ vs. $\mathrm{G}$. $n$ indicates the total number of $\mathrm{C}$ alleles; $N$ indicates the total number of $\mathrm{C}$ alleles plus $\mathrm{G}$ alleles. 
could be explained by the variability in vascular responsiveness to isoproterenol in the vascular bed associated with A46G polymorphism. ${ }^{35}$ Lang et al. ${ }^{36}$ and Johnson et al. ${ }^{37}$ provided a schematic diagram to explain the functional difference of vascular responsiveness in Africans and Caucasians. In Africans, the degree of vasodilatation and chronotropic effects in response to isoproterenol in the forearm was markedly higher than that of Caucasians, whereas baseline blood flow was similar in the two populations. In our meta-analysis, we demonstrated association of A46G polymorphisms with essential hypertension in the subgroup of the mixed African population, but not in Caucasians. The frequency of A46 homozygotes in the mixed African population was considerably higher in hypertensives than in normotensives, whereas no association could be found in other ethnicities. This suggests that the mechanisms responsible for blunted vasodilatation mediated by $\beta_{2}$-adrenoceptors in response to the administration of isoproterenol might contribute to enhanced vascular reactivity in Africans and might have a role in the pathogenesis of hypertension in Africans.

Some studies have reported that in G79 subjects, locally applied isoprenaline caused larger increases in forearm blood flow ${ }^{34}$ and dilation of hand veins ${ }^{34,35}$ than in C79 subjects. In other words, A46G polymorphisms and C79G polymorphisms seem to share similar mechanisms in conducting blood flow in resistance vessels. This is very likely due to the linkage disequilibrium between A46G and C79G. ${ }^{38-40}$ Owing to linkage disequilibrium, subjects homozygous for G79 are nearly always homozygous for G46, whereas naturally occurring A46/G79 is rare. ${ }^{41-43}$ Pojoga et al. ${ }^{6}$ observed that AA46/ CC79 was significantly associated with higher blood pressure, which might be attributed to the enhancement of the AA46/CC79 diplotype.

In conclusion, our meta-analysis suggests significant association between the ADRB2 A46G polymorphism and hypertension in the mixed African population. The ADRB2 C79G polymorphism had significant association with an $\mathrm{SBP} \geqslant 160 \mathrm{~mm} \mathrm{Hg}$ and/or $\mathrm{DBP} \geqslant 95 \mathrm{~mm} \mathrm{Hg}$ in the hypertensive population. The role of both polymorphisms might contribute to enhanced vascular reactivity to isoproterenol in capacitance vessels. ${ }^{34}$ More studies or large casecontrol studies, and especially studies stratified for different ethnicities and different stages of hypertension, should be performed to clarify the association between $A D R B 2$ polymorphisms and essential hypertension. Studies on the pathophysiologic mechanisms of the possible roles of A46G and C79G in hypertension are important as well.

\section{CONFLICT OF INTEREST}

The authors declare no conflict of interest.

\section{ACKNOWLEDGEMENTS}

This work was funded by grants 2008AA02Z441 of the National High Technology Research and Development Program, and grants 2008BAI52B03 of the National Eleventh Five-year Plan Program from the Ministry of Science and Technology of the People's Republic of China.

1 O'Shaughnessy KM. The genetics of essential hypertension. Br J Clin Pharmacol 2001; 51: 5-11.

2 Kobilka BK, Dixon RA, Frielle T, Dohlman HG, Bolanowski MA, Sigal IS, Yang-Feng TL, Francke U, Caron MG, Lefkowitz RJ. cDNA for the human $\beta 2$-adrenergic receptor: a protein with multiple membrane spanning domains and encoded by a gene whose chromosomal location is shared with that of the receptor for platelet-derived growth factor. Proc Natl Acad Sci USA 1987; 84: 46-50.

3 Green SA, Turki J, Innis M, Liggett SB. Amino-terminal polymorphisms of the human beta 2-adrenergic receptor impart distinct agonist-promoted regulatory properties. Biochemistry 1994; 33: 9414-9419.
4 Filigheddu F, Reid JE, Troffa C, PinnaParpaglia P, Argiolas G, Testa A, Skolnick M, Glorioso N. Genetic polymorphisms of the beta-adrenergic system: association with essential hypertension and response to beta-blockade. Pharmacogenomics J 2004; 4: 154-160.

5 Wu H, Tang W, Li H, Zhou X, Yang Y, Yu H, Li K, Xiao C, Deng AY. Association of the beta2-adrenergic receptor gene with essential hypertension in the non-Han Chinese $\mathrm{Yi}$ minority human population. J Hypertens 2006; 24: 1041-1047.

6 Pojoga L, Kolatkar NS, Williams JS, Perlstein TS, Jeunemaitre X, Brown NJ, Hopkins PN, Raby BA, Williams GH. Beta-2 adrenergic receptor diplotype defines a subset of salt-sensitive hypertension. Hypertension 2006; 48: 892-900.

7 Misono M, Maeda S, lemitsu M, Nakata Y, Otsuki T, Sugawara J, Zempo H, Yoshizawa M, Miyaki A, Kuno S, Matsuda M, Ajisaka R. Combination of polymorphisms in the beta2-adrenergic receptor and nitric oxide synthase 3 genes increases the risk for hypertension. J Hypertens 2009; 27: 1377-1383.

8 Castellano M, Rossi F, Giacchè M, Perani C, Rivadossi F, Muiesan ML, Salvetti M, Beschi M, Rizzoni D, Agabiti-Rosei E. Beta(2)-adrenergic receptor gene polymorphism, age, and cardiovascular phenotypes. Hypertension 2003; 41: 361-367.

9 Yu SF, Zhou WH, Jiang KY, Gu GZ, Wang S. Job stress, gene polymorphism of beta2-AR, and prevalence of hypertension. Biomed Environ Sci 2008; 21: 239-246.

10 Ge D, Huang J, He J, Li B, Duan X, Chen R, Gu D. Beta2-adrenergic receptor gene variations associated with stage-2 hypertension in northern Han Chinese. Ann Hum Genet 2005; 69: 36-44.

11 Mo W, Zhang GG, Yang TL, Dai XP, Li HH, Zeng H, Liu J, Tan YM, Zhou HH, Liu ZQ. The genetic polymorphisms of beta3-adrenergic receptor (AR) Trp64Arg and beta2-AR GIn27Glu are associated with obesity in Chinese male hypertensive patients. Clin Chem Lab Med 2007; 45: 493-498.

12 Candy G, Samani N, Norton G, Woodiwiss A, Radevski I, Wheatley A, Cockcroft J, Hall IP. Association analysis of beta2 adrenoceptor polymorphisms with hypertension in a Black African population. J Hypertens 2000; 18: 167-172.

13 Sunder-Plassmann G, Kittler H, Eberle C, Hirschl MM, Woisetschläger C, Derhaschnig $\mathrm{U}$, Laggner AN, Hörl WH, Födinger M. Angiotensin converting enzyme DD genotype is associated with hypertensive crisis. Crit Care Med 2002; 30: 2236-2241.

14 Xie HG, Stein CM, Kim RB, Gainer JV, Sofowora G, Dishy V, Brown NJ, Goree RE, Haines JL, Wood AJ. Human beta2-adrenergic receptor polymorphisms: no association with essential hypertension in black or white Americans. Clin Pharmacol Ther 2000; 67: 670-675.

15 Bartels NK, Börgel J, Wieczorek S, Büchner N, Hanefeld C, Bulut D, Mügge A, Rump LC, Sanner BM, Epplen JT. Risk factors and myocardial infarction in patients with obstructive sleep apnea: impact of beta2-adrenergic receptor polymorphisms. BMC Med 2007; 5: 1.

16 Kato N, Sugiyama T, Morita H, Kurihara H, Sato T, Yamori Y, Yazaki Y. Association analysis of beta(2)-adrenergic receptor polymorphisms with hypertension in Japanese. Hypertension 2001; 37: 286-292.

17 Herrmann SM, Nicaud V, Tiret L, Evans A, Kee F, Ruidavets JB, Arveiler D, Luc G, Morrison C, Hoehe MR, Paul M, Cambien F. Polymorphisms of the beta2 -adrenoceptor (ADRB2) gene and essential hypertension: the ECTIM and PEGASE studies. J Hypertens 2002; 20: 229-235.

18 Herrmann V, Büscher R, Go MM, Ring KM, Hofer JK, Kailasam MT, O'Connor DT, Parmer RJ, Insel PA. Beta2-adrenergic receptor polymorphisms at codon 16, cardiovascular phenotypes and essential hypertension in whites and African Americans. Am J Hypertens 2000; 13: 1021-1026.

19 Jia H, Sharma P, Hopper R, Dickerson C, Lloyd DD, Brown MJ. beta2-adrenoceptor gene polymorphisms and blood pressure variations in East Anglian Caucasians. J Hypertens 2000; 18: 687-693.

20 Gjesing AP, Andersen G, Burgdorf KS, Borch-Johnsen K, Jørgensen T, Hansen T, Pedersen 0 . Studies of the associations between functional beta2-adrenergic receptor variants and obesity, hypertension and type 2 diabetes in 7808 white subjects. Diabetologia 2007; 50: 563-568.

21 Mancia G, De Backer G, Dominiczak A, Cifkova R, Fagard R, Germano G, Grassi G, Heagerty AM, Kjeldsen SE, Laurent S, Narkiewicz K, Ruilope L, Rynkiewicz A, Schmieder RE, Boudier HA, Zanchetti A, Vahanian A, Camm J, De Caterina R, Dean V, Dickstein K, Filippatos G, Funck-Brentano C, Hellemans I, Kristensen SD, McGregor K, Sechtem U, Silber S, Tendera M, Widimsky P, Zamorano JL, Erdine S, Kiowski W, Agabiti-Rosei E, Ambrosioni E, Lindholm LH, Viigimaa M, Adamopoulos S, AgabitiRosei E, Ambrosioni E, Bertomeu V, Clement D, Erdine S, Farsang C, Gaita D, Lip G, Mallion JM, Manolis AJ, Nilsson PM, O'Brien E, Ponikowski P, Redon J, Ruschitzka F, Tamargo J, van Zwieten P, Waeber B, Williams B. 2007 Guidelines for the Management of Arterial Hypertension: the Task Force for the Management of Arterial Hypertension of the European Society of Hypertension (ESH) and of the European Society of Cardiology (ESC). J Hypertens 2007; 25: 1105-1187.

22 Ogihara T, Kikuchi K, Matsuoka H, Fujita T, Higaki J, Horiuchi M, Imai Y, Imaizumi T, Ito S, Iwao H, Kario K, Kawano Y, Kim-Mitsuyama S, Kimura G, Matsubara H, Matsuura H, Naruse M, Saito I, Shimada K, Shimamoto K, Suzuki H, Takishita S, Tanahashi N, Tsuchihashi T, Uchiyama M, Ueda S, Ueshima H, Umemura S, Ishimitsu T, Rakugi H. The Japanese Society of Hypertension Guidelines for the Management of Hypertension (JSH 2009). Hypertens Res 2009; 32: 3-107.

23 Woolf B. On estimating the relation between blood group and disease. Ann Hum Genet 1955; 19: 251-253.

24 Lau J, loannidis JP, Schmid CH. Quantitative synthesis in systematic reviews. Ann Intern Med 1997; 127: 820-826.

25 Petitti D. Meta-analysis, Decision Analysis, and Cost-effectiveness Analysis. Oxford University Press: New York, 1994. 
26 Egger M, Davey Smith G, Schneider M, Minder C. Bias in meta-analysis detected by a simple, graphical test. Br Med J 1997; 315: 629-634.

27 Tang W, Devereux RB, Kitzman DW, Province MA, Leppert M, Oberman A, Hopkins PN, Arnett DK. The Arg16Gly polymorphism of the beta2-adrenergic receptor and left ventricular systolic function. Am J Hypertens 2003; 16: 945-951.

28 Gu D, Su S, Ge D, Chen S, Huang J, Li B, Chen R, Qiang B. Association study with 33 single-nucleotide polymorphisms in 11 candidate genes for hypertension in Chinese. Hypertension 2006; 47: 1147-1154.

29 Tang W, Wu H, Zhou X, Cheng B, Dong Y, He L, Yu H, Xu L, Lu J, Li K, Xiao C. Association of the C-344T polymorphism of CYP11B2 gene with essential hypertension in Hani and Yi minorities of China. Clin Chim Acta 2006; 364: 222-225.

30 Deng W, Shi B, He X, Zhang Z, Xu J, Li B, Yang J, Ling L, Dai C, Qiang B, Shen Y, Chen R. Evolution and migration history of the Chinese population inferred from Chinese Y-chromosome evidence. J Hum Genet 2004; 49: 339-348.

$31 \mathrm{Hu}$ CJ, Wang CH, Lee JH, Hsieh CM, Cheng CC, Chang SC, Chang CJ. Association between polymorphisms of ACE, B2AR, ANP and ENOS and cardiovascular diseases: a community-based study in the Matsu area. Clin Chem Lab Med 2007; 45: 20-25.

32 Lee YW, Oh VM, Garcia E, Taylor EA, Wu H, Yap EP, Kazeem GR, Caulfield MJ, Munroe PB. Haplotypes of the beta2-adrenergic receptor gene are associated with essential hypertension in a Singaporean Chinese population. J Hypertens 2004; 22: 2111-2116.

33 Xu S, Yin X, Li S, Jin W, Lou H, Yang L, Gong X, Wang H, Shen Y, Pan X, He Y, Yang Y, Wang Y, Fu W, An Y, Wang J, Tan J, Qian J, Chen X, Zhang X, Sun Y, Zhang X, Wu B, Jin L. Genomic dissection of population substructure of Han Chinese and its implication in association studies. Am J Hum Genet 2009; 85: 762-774.
34 Cockcroft JR, Gazis AG, Cross DJ, Wheatley A, Dewar J, Hall IP, Noon JP. 2-Adrenoceptor polymorphism determines vascular reactivity in humans. Hypertension 2000; 36: 371-375.

35 Dishy V, Sofowora GG, Xie HG, Kim RB, Byrne DW, Stein CM, Wood AJ. The effect of common polymorphisms of the beta2-adrenergic receptor on agonist-mediated vascular desensitization. N Engl J Med 2001; 345: 1030-1035.

36 Lang CC, Stein CM, Brown RM, Deegan R, Nelson R, He HB, Wood M, Wood AJ. Attenuation of isoproterenol-mediated vasodilatation in blacks. N Engl J Med 1995; 333: $155-160$.

37 Johnson JA, Burlew BS, Stiles RN. Racial differences in beta-adrenoceptor-mediated responsiveness. J Cardiovasc Pharmacol 1995; 25: 90-96.

38 McGraw DW, Forbes SL, Kramer LA, Liggett SB. Polymorphisms of the $5^{\prime}$ leader cistron of the human beta2-adrenergic receptor regulate receptor expression. J Clin Invest 1998; 102: 1927-1932.

39 Drysdale CM, McGraw DW, Stack CB, Stephens JC, Judson RS, Nandabalan K, Arnold K, Ruano G, Liggett SB. Complex promoter and coding region beta 2-adrenergic receptor haplotypes alter receptor expression and predict in vivo responsiveness. Proc Natl Acad Sci USA 2000; 97: 10483-10488.

40 Belfer I, Buzas B, Evans C, Hipp H, Phillips G, Taubman J, Lorincz I, Lipsky RH, Enoch MA, Max MB, Goldman D. Haplotype structure of the beta adrenergic receptor genes in US Caucasians and African Americans. Eur J Hum Genet 2005; 13: 341-351.

41 Small KM, McGraw DW, Liggett SB. Pharmacology and physiology of human adrenergic receptor polymorphisms. Annu Rev Pharmacol Toxicol 2003; 43: 381-411.

42 Kirstein SL, Insel PA. Autonomic nervous system pharmacogenomics: a progress report. Pharmacol Rev 2004; 56: 31-52.

43 Leineweber K, Büscher R, Bruck H, Brodde OE. Beta-adrenoceptor polymorphisms. Naunyn Schmiedebergs Arch Pharmacol 2004; 369: 1-22. 